Int. Archs Allergy appl. Immun. 1982;68:I-V

\title{
Contents, Vol. 68, 1982
}

\section{No. 1}

Original Paper

Studies on Allergen and Allergoid Preparations from Purified

Timothy (Phleum pratense) Pollen Extracts. I. Physico-

chemical Characteristics and Binding to Allergen-Specific

Human IgE

Puttonen, E.; Maasch, H.J.; Pilström, L 1

Studies on Allergen and Allergoid Preparations from Purified

Timothy (Phleum pratense) Pollen Extracts. II. Anaphylaxis

Studies in Rats and Histamine Release from Human Leu

kocytes

Puttonen, E.; Pilström, L.; Wahn, U.; Maasch, H.J 7

Effect of Beta-Adrenergic Agents on Immunoglobulin G Levels

in Asthmatic Subjects

Mansfield, L.E.; Nelson, H.S 13

In vitro Effect of Asbestos Fibers on Polymorphonuclear Leukocyte Function Doll, N.J.;

Stankus, R.P.; Goldbach, S.; Salvaggio, J.E. . . 17

Phagocytosis, Chemoluminescence, and Intracellular Killing of Fungi by Phagocytes from

Subjects with Deficiency of the Second Component of Complement Meuwissen, H.J.; Rhee,

M.S.; Rynes, R.I.; Pickering, R.J. . 22

Collagen-Anti-Collagen Complexes in Rheumatoid Arthritis

Sera

Wozniczko-Orlowska, G.; Milgrom, F

28

Antigenicity of Beta-Lactam Antibiotic Preparations: Produc

tion of IgE Antibodies to Beta-Lactam Antibiotic and Their

Cross-Reaction Within the Antibiotic Group

Iwata, M.; Katsuta, M.; Tanii, T.; Tokiwa, H.; Matuhasi,

$\mathrm{T} \quad .35$

The Effect of Antibody on the Intestinal Absorption of Macro-

molecules and on Intestinal Permeability in Adult Mice

Lim, P.L.; Rowley, D 41

Experimental Antigen-Antibody Complex Disease in Mice. The Role of Antibody Levels, Antibody Affinity and Circulating Antigen-Antibody Complexes Devey, M.E.; Bleasdale, K.;

Collins, M.; Steward, M.W. . 47

Immune Responses of Guinea Pigs to Dietary Protein. I. Induc

tion of Tolerance by Feeding with Ovalbumin

Heppell, L.M.J.; Kilshaw, P.J 54

Anti-DNA, Anti-Deoxyribonucleoprotein and Rheumatoid Factor Measured by ELISA in

Patients with Systemic Lupus Erythematosus, Sjögren's Syndrome and Rheumatoid Arthritis 
Karsh, J.; Halbert, S.P.; Anken, M.; Klima, E.; Steinberg,

A.D. 60

Comparative Studies on Tree-Pollen Allergens. III. A Purified

Low Molecular Weight Major Allergen from Birch Pollen

(Betula verrucosa) Isolated by Gel Permeation Chromatog-

raphy

Vik, H.; Elsayed, S.; Apold, J.; Paulsen, B.S 70

Modulation of Polymorphonuclear Leukocyte Chemilumines-

cent Response to the Chemoattractant f-Met-Leu-Phe

Dahlgren, C; Magnusson, K.-E.; Stendahl, O.; Sund-

qvist, $\mathrm{T} \quad 79$

Differential Cyst(e)ine Requirements in Human T and B Lymphoblastoid Cell Lines

Kamatani, N.; Carson, D.A 84

Short Communications

Evidence for the Carter Effect in Atopy

Happle, R.; Schnyder, U.W 90

Phosphatidic Acid Induces Histamine Secretion from Rat Peri toneal Mast Cells

Pearce, F.L.; Messis, P.D 93

Book Reviews 96

No. 2

Original Paper

Palytoxin both Induces and Inhibits the Release of Histamine from Rat Mast Cells

Chhatwal, G.S.; Ahnert-Hilger, G.; Beress, L.; Haber-

mann, E 97

Subthreshold and Suboptimal Desensitization of Human Basophils. I. Kinetics of Decay of Releasability

Mendoza, G.R.; Minagawa, K 101

Hypersensitivity Pneumonitis in Strain II Guinea Pigs. I. Histologic Features

Schuyler, M.; Schmitt, D.; Steinberg, D 108

Hypersensitivity Pneumonitis in Strain II Guinea Pigs. II. Immunologic Features

Schuyler, M.; Schmitt, D.; Steinberg, D 112

Potentiated Immune Responses after Administration of Aclacinomycin

Orbach-Arbouys, S.; Andrade-Mena, C.E.; Berardet, M.;

Mathe, G 117

Pathomechanisms of Dextran-Induced Anaphylactoid/Ana-

phylactic Reactions in Man

Hedin, H.; Richter, W 122

The Increase of a Normally Occurring K Cell Population during Progressive Tumor Growth in Mice

Gadol, N.; Saluk, P.H 127 
Detection of Antibody to Carcinoembryonic Antigen by the

Hemolytic Plaque Assay

Stinson, R.S.; Lockhart, C.G.; Margraf, H.W.; Philpott,

G.W 134

Histochemical Patterns of Human T Lymphocyte Subpopula-

tions with Nonspecific Esterase Staining

Quesada, J.R.; Murphy, S.G 138

IV

Contents

Characterization of the Carbohydrate Moiety in a Purified Allergen Preparation from the Mite Dermathophagoides Farinae and Its Importance for Allergenic Activity as Tested by the RASTInhibition Method Wolden, B.; Paulsen, B.S.; Wold, J.K.; Grimmer, 0. ... 144

Experimental Study on Immunological Reactions against the Articular Cartilage Yoshioka, Y.;

Tsuru, S.; Yokoyama, M.; Nomoto, K. . 152

The Appearance of Specific Helper Cells in Lymph of Immu nized Sheep

Heron, I.; Cahill, R.; Trnka, Z157

Non-IgGl Nature of Cutaneous Basophil Hypersensitivity Fac tor in Contact Sensitivity

Katayama, I.; Nishioka, K.; Nishida, K.; Doi, T 164

Enhancement of E Rosette Formation by Incubation of Lym

phocytes in Cerebrospinal Fluid Dilutions

Næss, A 169

Short Communications

IgE Anti-Brucella Antibodies in the Course of Human Brucel

losis and after Specific Vaccination

Escande, A.; Serre, A 172

The Mechanism of Ketotifen-Induced Histamine Release from

Human Peripheral Leucocytes

Moodley, I.; Davies, R.J 176

Presence of Fibronectin in Cold Precipitates of Patients with

Cryoimmunoglobulinemia

Levo, Y 179

Processing of Orally Absorbed Immunogen

Lim, P.L.; Rowley, D 182

Enhancement of the Anaphylactoid Reaction in Rats by Salicylates

West, G.B 185

A Possible Link between the Ability of Rat Isolated Peritoneal

Mast Cells to Release Histamine when Challenged with

Dextran and the Proteins in Their Plasma Membranes

Ludowyke, R.I.; West, G.B.; Harris, J.R.; Hanahoe,

T.H.P 188

Book Reviews

192

News Items 192 
No. 3

Original Paper

Low Levels of Antibodies to Surface Antigens of Group B

Streptococci in Commercial IgG Preparations

Linden, V.; Christensen, K.K.; Christensen, P

Immunologic Cross-Reactivity between Spinal Cord Protein

and Myelin Basic Protein

Ramshaw, I.A.; Welter, D.; MacPherson, C.F.C 196

Role of C4-Binding Protein in the Defective Lysis of Sensitized

Sheep Erythrocytes by Mouse Complement

Amerongen, A. van; Dijk, H. van; Willers, J.M.N 201

Adjuvanticity of Dimethyl Dioctadecyl Ammonium Bromide

in Guinea Pigs. I. Skin Test Reactions

Snippe, H; De Reuver, M.J.; Kamperdijk, E.W.A.; Berg,

M. van den; Willers, J.M.N 206

A Micromethod for the Detection of Tg and TM Cells. Techni

cal Aspects for the Enumeration of Human T-Cell Subpop-

ulations

Jensen, J.R 214

Quantification of the C3 Breakdown Product C3d by Rocket Immunoelectrophoresis

Ramentol-Massana, M.; Grau, G.; Beaumariage, M.-L.;

Salmon, J 219

Use of Isotachophoresis for Identification of Pollen Allergens

Einarsson, R.; Karlsson, R 222

Characterization and Mitogenesis of Feline Lymphocyte Popu

lations

Rojko, J.L.; Hoover, E.A.; Finn, B.L.; Olsen, R.G 226

Standardization of the Double-Antibody Method for IgE De

termination: Use of Different Monoclonal IgE as Tracer,

Immunogen or Standard

Popa, V.; Reardon, M 233

Effects of Parenteral Keyhole Limpet Hemocyanin or Cholera Toxin on Intestinal Immune

Response to Keyhole Limpet Hemocyanin Hamilton, S.R.; Keren, D.F.; Yardley, J.H.; Brown,

G. . . 242

Total Body Irradiation Allows Reinduction of Allergic Ence-

phalomyelitis in Convalescent Lewis Rats

Willenborg, D.0 247

Assessment of Murine Lymph Node Lymphocyte Priming with

the Tetrasialoganglioside $\mathrm{Gq}^{1 / 8}$

Sela, B.-A 252

Serum and Salivary IgA Levels in Normal Subjects: Comparison between Tonsillectomized and

Non-Tonsillectomized Subjects

D’Amelio, R.; Palmisano, L.; Le Moli, S.; Seminara, R.;

Aiuti, R 256 
Thymus Dependence of the Adoptive Transfer of Intestinal

Mastocytopoiesis in Trichinella spiralis-lnfected Mice

Parmentier, H.K.; Ruitenberg, E.J.; Elgersma, A 260

The Immune Response to Bee Venom. Comparison of the Antibody Response to Phospholipase A2 with the Response to Inhalant Antigens

Kemeny, D.M.; Miyachi, S.; Platts-Mills, T.A.E.; Wilkins,

S.; Lessof, M.H 268

Specific Inhibition of Contact Sensitivity in the Guinea Pig fol

lowing Tolylene Diisocyanate Inhalation

Doe, J.E.; Hicks, R.; Milburn, G.M 275

Short Communications

Potentiation of MIF Production by Lymphocytes of Trichinella

spiralis-lnfccteà Mice

Blackwood, L.L.; Platt, D.; Molinari, J.A 280

Rectal Absorption of Dextran in Rats in the Presence of Salic-

ylates

West, G.B 283

Is it Possible to Predict the Clinical Effect of Hyposensitiza-

tion?

Østerballe, O.; Løwenstein, H.; Mailing, H.-J.; Petersen,

B.N.; Weeke, B 286

Contents

$\mathrm{V}$

No. 4

Original Paper

Fractionation and Biological Characterization of Olea europea Pollen Extract

Vela, C; Platas, C; Gurbindo, C; Tricas, L.; Subiza, E.;

Garcia, R.; Lahoz, C 289

Allergens from Plantain (Plantago lanceolata). Studies with Pollen and Plant Extracts Baldo,

B.A.; Chensee, Q.J.; Howden, M.E.H.; Sharp, P.J. . 295

Hemolytic Capacity of Human Monocytes in Normal Subjects

De Young, N.J.; Gill, P.G 305

Studies of Chemically Modified Honeybee Venom. I. Biochem

ical, Toxicologic and Immunologic Characterization

Mueller, U.; Reisman, R.; Elliott†, W.; Steger, R.; Walsh,

S.; Wypych, J.; Arbesman, C 312

Studies of Chemically Modified Honeybee Venom. II. Immu-nogenicity and Suppression of

Reaginic Antibody Formation Mueller, U.; Reisman, R.; Wypych, J.; Arbesman, C. ... 320

A Possible Role of Arachidonate Metabolism in Allergic Air Pouch Inflammation in Rats. AntiInflammatory Effect of Indomethacin and Dexamethasone and the Level of Prosta-glandin E2 in the Exudate

Ohuchi, K.; Yoshino, S.; Kanaoka, K.; Tsurufuji, S.; Le-

vine, L 326

Inhibitory Effect of Traxanox Sodium on IgE-Mediated Hista-

mine Release from Passively-Sensitized Mast Cells of the 
Rat in vitro

Goto, K.; Hisadome, M.; Terasawa, M 332

Isolation of Human Suppressor T Cells by Peanut Agglutinin

Nakamura, T.; Tanimoto, K.; Nakano, K.; Horiuchi, Y. . 338

Antigen-Induced Release of Histamine from Rat Tissues in

vitro: Dissociation in Development of Serosal Mast Cell,

Lung Tissue, and Tracheal Tissue Response Capacity

Bergstrand, H.; Frick, I.-M.; Lindhqvist, V.; Lundqvist, B.;

Nyström, I.; Schurmann, A 342

Development and Use of Three New Radioallergosorbent Tests

in the Diagnosis of Penicillin Allergy

Edwards, R.G.; Spackman, D.A.; Dewdney, J.M 352

Factors Mediating the Binding of Immune Complexes to Cryo-

stat Sections of Psoriatic Lesions

Bjerke, J.R.; Krogh, H.-K.; Matre, R 358

Increased Complement-Mediated Leukocytic Histamine Release in Atopies

Radermecker, M.; Maldague, M.P.; Gustin, M 365

Comparative Studies on Tree Pollen Allergens. IV. Evaluation

of Two Commercially Available Allergen Extracts of Alder

(Alnus incana) and Birch (Betula verrucosa) Pollen

Vik, H.; Florvaag, E.; Apold, J.; Paulsen, B.S.; Elsayed, S. . 371 Chitin: An Immunological

Adjuvant and a Polyclonal B-Lym-

phocyte Activator

Diamantstein, T.; Klos, M.; Osawa, H.; Chen, Z.C 377

In vitro Effect of Ethanol on Subpopulations of Human Blood

Mononuclear Cells

Gilhus, N.E.; Matre, R

New Insight into Lymphocytic Chalone Research. The 'Facteur

Thymique Sérique' Might Be Responsible for Part of the

Immunosuppressive Activity Detected in the 'Chalone

Fraction'

Lenfant, M.; Millerioux, L 387

Differential Capacity of Macrophages from Various Sources to

Act as Hapten-Specific Stimulator Cells in vitro

Blomberg, M. von; Scheper, R.J.; Mullink, H.; Polak, L. . 392

Short Communications

Nippostgrongylus brasiliensis Infection in the Rat: Effects of

Surgical Removal of Peyer's Patches, Mesenteric Lymph

Nodes and Spleen

Heatley, R.V.; Befus, A.D.; Bienenstock, J 397

Ethylenediamine Tetraacetic Acid and Histamine Release from

Rat Mast Cells

West,G.B 399

Author Index 402 